УДК 821.161.2-32.09 Леся Українка

Горболіс Лариса, доктор філологічних наук, професор, професор кафедри української мови і літератури Сумський державний педагогічний університет імені А. С. Макаренка

\title{
МУЗИЧНА ОСНОВА ОПОВІДАННЯ ЛЕСІ УКРАЇНКИ «НАД МОРЕМ»
}

\begin{abstract}
У статті із застосуванням інтермедіалъного підходу досліджуютъся особливості художнъого відтворення музики в оповіданні «Над морем» украӥнсъкоӥ писъменнищі Лесі Украӥнки, аналізуєтъся роль пісенъ, музики оркестрів, звуків моря тощо у формуванні музичної палітри твору. Море в акустичному обормленні оповідання виконує ключову роль, характеризуе героїв, створюе настроєву палітру твору, психологізуе важливі сюжетотворчі епізоди.
\end{abstract}

Звернення Лесі Українки до музики в оповіданні «Над морем» потрактовуетъся як необхідність оптимізувати поетикалъні можливості прози, оновити й осучаснити жсанр оповідання, відкрити його незапитані можливості, інтелектуалізувати прозу, урізноманітнити й удосконалити художні прийоми й засоби змалювання складного внутрішнъого світу персонажів. Море, що $\epsilon$ функиіональною складовою музичної палітри оповідання Лесі Українки, органічно зв'язане з проблематикою, сюжетом твору, має свою «історію взаємин» із головною героӥнею; це самодостатній пейзажсний компонент, що утримуе настроєвий баланс твору, корпус переживань $i$ дій героӥні-нараторки. Музика $i$ море у творі тісно контактують, утворюють неперервну й водночас неодноманітну за емоційним наповненням лінію, характеризують героӥнъ. Відповідно до модерністсъкої практики Леся Українка представляе головну героӥню - чутливу, вразливу, емоційну, яка сприймає досконалі звуки й неперевершені кольори моря як гармонію.

Панорамні візуально-акустичні описи водної стихї̈ в оповіданні Лесі Українки, а також численні листи писъменниці дають підстави говорити про море як енергетичний канал, джерело емоційного й тілесного відновлення героїні й авторки, своерідну вісъ, що тримае смислову конструкцію твору. Енергія, звуки моря художнъо увиразнюють ідею захищеності героӥні, котра усвідомлюе иінність $i$ повноту буття. На основі листів Лесі Українки обљрунтовано доцілъність потрактовувати терапевтично-лікувальну роль звуків, кольору моря.

Ключові слова: музика, звуки, ритм, оповідання, інтермедіальність, екзистенційна проблематика, нараторка. 


\begin{abstract}
Horbolis L. The musical basis the story «Aboye the sea» by Lesya Ukrainka.

The article, using the intermedial approach, explores the features of the artistic reproduction of music in the story «Above the Sea» by the Ukrainian writer Lesya Ukrainka. It analyzes the role of songs, music of orchestras, sounds of the sea, etc. in the formation the musical palette of the work. The sea plays the key role in the story acoustic design, characterizes the heroes, creates a moody palette of the work, and psychologizes important plot-creating episodes.
\end{abstract}

Lesya Ukrainka's using music in the story «Above the Sea» is interpreted as the need to optimize poetic potentials of prose, to update and modernize the genre of the story, to discover its unexplored possibilities, to intellectualize prose, to diversify and improve the artistic techniques and means of depicting the complex inner world of characters. The sea is a functional component of the musical palette of Lesya Ukrainka's story. It is organically connected with the problematic, the plot of the work, has its own «history of relations» with the main character; it is a self-contained landscape component that keeps the mood balance of the work, the complex of experiences and actions of the storyteller. In the work music and the sea are in close contact, form a continuous and at the same time nonuniform emotional line, which describing the characters. According to modernist practice, Lesya Ukrainka represents the main character like a sensitive, vulnerable, emotional, and one, who perceives perfect sounds and unsurpassed colors of the sea as harmony.

Panoramic visual and acoustic descriptions of the water element in Lesya Ukrainka's story, as well as her numerous letters give us a reason to talk about the sea as an energy channel, a source of emotional and bodily recovery of the heroine and the author, a kind of axis, keeps the semantic structure of the work. The energy and the sounds of the sea artfully express the idea of the protection of heroine, who is aware of the value and fullness of life. Based on Lesya Ukrainka's letters, it is reasonable to interpret the therapeutic role of sea sounds and colors.

Key words: music, sounds, rhythm, stories, intermedialism, existential issues, storyteller.

Постановка проблеми. Звернення до оповідання Лесі Українки «Над морем» викликане потребою конкретизувати місце, роль і значення прозового доробку письменниці в літературному процесі кінця XIX початку XX ст., у виробленні й утвердженні запитаних для українського письменства засобів психологізації та інтелектуалізації української прози. Активізація новітніх методологій, увага до художнього тексту, цілеспрямоване заглиблення у творчу лабораторію митця, проникнення в психологічні особливості письма, різногранне осмислення складних життєвих обставин письменника, а також розкодування функціонально важливих міжмистецьких включень посутньо оптимізують сучасний літературознавчий дискурс й означують шляхи перепрочитання української класики. «Над морем» належить до маловивчених текстів і потребує повноти інтерпретації, а означена в заголовку статті проблема є складовою у комплексному підході до аналізу твору.

Аналіз останніх досліджень. Різножанрові твори Лесі Українки від часу їх появи по сьогодні є об'єктом багатоаспектних досліджень 
182 Літератури світу: поетика, ментальність і духовністъ. 2020. Bип.14

літературознавців (В. Агеєва, А. Диба, А. Бичко, Л. Демська-Будзуляк, О. Забужко, Н. Колошук, М. Кудрявцев, Л. Масенко, Л. Мірошниченко, Л. Скупейко та ін.). Не становить винятку і проза, яка, слід визнати, останнім часом перебуває дещо поза увагою дослідників. Окрім праці Л. Кулінської «Проза Лесі Українки» (К., 1976), де запропоновано системний аналіз прози письменниці, нині не існує комплексних студій. Прозовий доробок письменниці посідає помітне місце не лише в їі творчості, а й у літературі кінця XIX - початку XX ст. в цілому. До аналізу самобутньої прози Лесі Українки слушно застосовувати новітні методології, зокрема й популярний у сучасному літературознавстві інтермедіальний підхід, що вже мали нагоду продемонструвати [1].

Мета статті - виявити й проаналізувати особливості художнього оприявлення музики в оповіданні Лесі Українки «Над морем».

Виклад основного матеріалу. Оповідання Лесі Українки «Над морем» написане 1898 р. (рукописний авторський примірник із датою «19.XI.1898, Київ» зберігся в архіві I.Франка, вперше надрукований у журналі «Літературно-науковий вісник» 1901, кн. 1, 2). Текст оповідання, а також листи Лесі Українки з Криму з червня 1897 р. по червень 1898 р. дають підстави говорити про наявність автобіографічних елементів у творі, що властиво доробку письменниці, адже, як зауважує Л. Мірошниченко, «творчість Лесі Українки ... органічно злита з ї̈ особистістю, $i$ подї $\dddot{\imath}$ життя, до найінтимніших моментів «біографії душі», стають природним, таким важливим для розуміння коментарем до текстів, так само як тексти - ключем до ї̈ життя» [2, с. 20]. В українській літературі кінця XIX - початку XX ст., як відомо, твори з автобіографічним компонентом представлені доволі активно.

Листи письменниці є важливим кодом для студіювання оповідання «Над морем», твору, що потребує повноти інтерпретації з акцентуванням на вивчення музичних засад. Слушно навести з епістолярію Лесі Українки кілька фактів про її мешкання в «оригінальному дворi» $[3$, с. 396] в Ялті, згодом заявлені в оповіданні «Над морем». Скажімо, в листах до рідних письменниця повідомляе про співмешканку слухачку московських фельдшерських курсів: «Вона нічого собі дівчина, та все-таки зовсім чужа, а я не люблю, як хтось чужий стримить повсякчас у пене перед очима» [3, с. 380]. А в іншому листі додає до характеристики співмешканки: "Добре бути такою натурою, як моя "товаришка", ій всвого 20 літ, але вона вже зложила собі певні категоричні мірки і рамки $і$ вірить в них без критики. Се навіть часом мене дражнить» [3, с. 380]. Ця співмешканка і стала прототипом 
героїні Алли Михайлівни, яка також із Москви, має схожу вдачу, чужа нараторці за поглядами, життєвими принципами. Психотип нараторки суголосний характеру, світогляду, переконанням Лесі Українки. Деякі факти з життя письменниці в Криму також відповідають епізодам із оповідання, наприклад, головна героїня, як і Леся Українка, шиє (порівняймо з листа від 2 січня 1898 р.: «Не люблю я страх сеї роботи, та дуже тут дорого беруть за шиття» [3, с. 419]).

3 огляду на тему нашого дослідження слушно зауважити і про «музичну сторону» перебування Лесі Українки в Криму. Із листів відомо, що в Ялті в неї було фортепіано [3, сс. 371, 401]; вона не лише грає, а й вчить Катерину Дерижанову - дружину лікаря, який їі лікує, в будинку якого мешкає. Катерина грає щодня, зауважує Леся Українка в одному з листів [4, с. 24]. Відомо також, що Леся Українка просить матір надіслати ноти «Крейцерової сонати» Бетховена, [4, с. 18], XII шумку М. Завадського [4, сс. 27, 44]; повідомляє про отримані ноти М. Левицького $[4$, с. 48$]$ - ковельського лікаря, письменника й композитора, культурного діяча, який створив музику до поезії Лесі Українки «Колискова» і надіслав поетесі ноти.

Художньо трансльована музика в оповіданні Лесі Українки «Над морем» заявлена в різних проявах: музичними термінами, фрагментами пісень (наспівів), оркестром, а також за допомогою стилістичних засобів виразності; музика бере активну участь у побудові епізодів, характеристиці героїв, розгортанні подієвості твору, відображенні настроїв, переживань, емоційних станів героїв, внутрішньо структурує твір, урізноманітнює стильову фактуру оповідання, бере участь у панорамному зображенні образу моря.

Звернення Лесі Українки до музики в оповіданні «Над морем» засвідчує необхідність оптимізувати поетикальні можливості прози, оновити й осучаснити жанр оповідання (як відомо, в цей час популярності набуває новела), відкрити його незапитані можливості, інтелектуалізувати прозу. Не варто відкидати й факт постійного прагнення письменниці психологізувати українську літературу, урізноманітнювати й удосконалювати художні прийоми й засоби змалювання складного внутрішнього світу персонажів.

Море, що є функціональною складовою музичної палітри оповідання Лесі Українки, по-перше, органічно зв'язане з проблематикою, сюжетом, по-друге, має свою «історію взаємин» із головною героїнею; по-третє, будучи вповні самодостатнім пейзажним компонентом, утримує настроєвий баланс твору, корпус переживань і дій (внутрішніх i зовнішніх) героїні-нараторки. Притишено-спокійний початок 
184Літератури світу: поетика, ментальність і духовністъ. 2020. Bип.14

оповідання - перше, однак доволі промовисте, знайомство з головною героїнею (у творі вона без імені), яка віддає перевагу усамітненню, а не спілкуванню з людьми, заперечуючи в своїй натурі мізантропію: «...хочеться на якийсь час втекти від людей власне для того, щоб не почати ненавидіти їx» [5, с. 159]. Початок твору показовий, адже «за кадром» залишається зрада, непорядність, заздрість людей. Протистояння з цим негативом у героїні, як засвідчують її роздуми, вже відбулося. Вона перемогла, проте виснажилася - тепер віднайшла джерело зцілення в природному й довершеному ритмі моря. Море стає для героїні тим енергетичним конструктом, що наснажує її життя сенсом, зцілює тіло, а для Лесі Українки море стає ще й потужним джерелом творчості.

Із перших рядків твору головна героїня постає як особистість, котра розуміє цінність свободи, здатна осягати повноту буття й вартісність роботи над собою. У презентації нараторки ключову роль відіграє саме море, могутня водна стихія. Ось лише фрагмент опису 3 помітною звуковою домінантою: «Море шуміло, дрібні каміниі торохтіли, зачеплені хвилею, немов порікували, зо їм не дає спокою химерна вода. Чайки цілими зграями літали над водою, жалібно скиглячи. . Завжди поважні кримські садки стояли тихо... Каміння $i$ скелі над берегом здавались ще більше нерухомими проти вічно живого, вічно рухомого моря, що при кожній хмариі, при кожній зміні небесного світла переміняло свій вид, але ніколи не розбивало гармонї картини» [5, с. 160]. Море асоціюється в нараторки з гармонією, яку руйнують різкий, мідяний гук військового оркестру, уривок солдатської пісні, свист парохода, а коли на берег розгнівана хвиля викидала лушпиння, старі черевики і «всілякі злидні людсъкі», тоді «гармонія раптом розбивалася, мрія про незаселену людъми краӥну зникала» $[5$, c. 160]. Так за допомогою моря окреслюється конфлікт героїні 3 байдужим зовнішнім світом.

Для детальної характеристики музичної палітри оповідання й «участі» в ньому моря слушно звернутися до епістолярію, де описані враження Лесі Українки від цієї стихії, переживання їі краси, що сприятиме максимальному заглибленню у внутрішній світ, емоційний стан, переживання головної героїні оповідання «Над морем». Численні відгуки Лесі Українки про море (в різний час доби чи пори року) сповнені прихильності, попри його бурхливість чи нестриманість. У мисткині немає до нього неприязні. Таку прихильність виявляємо і в аналізованому оповіданні, як-от: «То була весела літня буря...»[5, с. 180]. Нараторка прихильна до моря, як 
і Леся Українка, що засвідчують їі листи: «...море як дзеркало, $i$ їздити по нъому се просто втіха, варта богів» [3, с. 379], «Вдень тут тепло, часто громові бурі набігають, море таке чудово гарне, як ніколи літом не бувало» [3, с.386], «Море часом досить тихе $<\ldots>$ Я ж його щосъ ніколи не боюсъ, $i$, далебі, я певна, що воно куди добріше від людей: як втопить, то вже втопить, а довго не мучить, принаймні хто сам до нъого не лізе, воно того не зачіпае. Я могтиму сказати про нъого, як Гейне сказав: "Wir waren einander gut"» [3, с. 388]. Море її заспокоює, скеровує на роздуми: «... щ щодя швендяю над морем "словно овца беспредельная", $і$ се немало розважае мене. Врешті, нічого иікавого зоокола, приходиться, отже, більше «себя собою наполняя и из себя собой сияя...» [3, с. 409]. Море - друг, порадник у моменти її одинокості. Численні описи настрою та кольору моря представлено в багатьох листах письменниці [3, сс. 392-393, 418, 419] [4, сс. 14-15, 50 та ін.]. Прикметно, що звуків моря в листах заявлено небагато ( несамовито (письмівка моя. - Л.Г.), наче хоче послухати мене $i$ затопити Крим» [3, с. 385]) - письменниця ніби залишає на потім гаму звуків моря, щоб згодом перенести їх в оповідання.

Море в оповіданні Лесі Українки «Над морем» характеризує нараторку, а введені різноманітні музичні фрагменти (пісні, музика оркестру тощо) представляють протилежну за світоглядом і життєвими принципами героїню - Аллу Михайлівну, яка не любить «розводити сантиментів з природою» [5, с. 177]. Співбесідниця говорила, «перебиваючи сама себе раз у раз - то співами, то якимсь чудним гуком, що вона називала “иыганским взвизгиванвем” [5, с. 161], наспівувала різні пісні («"О море, море, о ночь любви!.." - завела вона ненатуральним, горловим голосом» [5, с. 161], «Я гуляю, слез не знаю, распеваю...» [5, с.162], «...голос Алли Михайлівни, що виводив з притиском на ферматах: "До самой зари, до рассвета/ Он жарко меня целовал... ”» [5, с. 167] тощо). До невдало проспіваних із сумнівним змістом мелодій долучається інформація про домівку Алли Михайлівни, Москву, коли вони разом із братом і його товаришами вирушали на трійках-конях із циганами на прогулянки: «Baм om цигансъкі романси не до сподоби, а коли б ви почули, як їх сами цигани співають: "Мы в тишине, наедине..."” [5, с. 163]. Фрагменти пісень у виконанні Алли Михайлівни характеризують її як людину нецікаву, поверхову. Реакція нараторки на дівчину та ї̈ спів також промовиста: «Ї̈ гарне, з тонкими рисами лице пройняло такий "цъганский" вираз, що мені стало невимовно шкода ї̈, так як бувало шкода малих дітей 
186Літератури світу: поетика, ментальність і духовністъ. 2020. Bип. 14

в цирку, коли вони показують чужим людям свої тоненъкі виламані miльия» [5, с. 163]. Доповнює образ дівчини й низка показових штрихів: «Панночка, одягаючись, так зашелестіла $i$ зарипіла шовками, що нерви мої не витримали съого прикрого для мене шелесту, $i$ я вийшла...» [5, с. 166], «безжурне щебетання моєї бесідниці робили на мене якесъ тяжке, сливе тригічне враження...» [5, с. 169]. Непрямим доповненням характеристики Алли Михайлівни є її приятель Анатоль, «що мугикав шансоньєтку: "Це не суn, це шоколад"» [5, с. 179], а також висловлена дівчиною неприхильність до музичної освіти своєї сестри, яка, навчаючись у консерваторії, «мучиласъ, мучиласъ, виламувала пальці і всім життя труїла своїми вправами, а тепер навіть не грае...» [5, с. 182].

У хвилини внутрішньої дисгармонії і спричинених людьми та зовнішньою какофонією роздратування нараторка постійно знаходила спокій та розраду у спогляданні моря, як-от: «... у вузъкій щілині міюс кипарисами сміялося море свіжим іскристим усміхом, що викликав ясний усміх $i$ в мене...» [5, с. 161]. Головна героїня налаштовує тональність розмови з морем, що підтримує їі емоційних стан, скеровує на позитивний лад. Музика (оркестрів чи як супровід пісні тощо) і море вступають у тісний контакт, по-перше, утворюючи неперервну i, що прикметно, неодноманітну за емоційним наповненням лінію, по-друге, різнобічно характеризуючи обох героїнь, адже музика моря імпонує нараторці, а музика оркестрів, невигадливі пісеньки подобаються Аллі Михайлівні. Про несхожість цих героїнь свідчить і епізод, коли Алла Михайлівна пропонує піти до павільйону, пояснюючи: «... се ж на морi, вам повинно подобатисъ. Ви будете на своє прекрасне море дивитись, а я на людей» [5, с. 175]. «Хто більше побачить!..» [5, с. 175] - 3 підтекстом відповіла нараторка, яка вміє бачити в людях і природі потаємне, приховане, непомітне.

Алла Михайлівна постійно декларує байдужість до природи, як-от: «Мені задається, що то більше так, для годиться розпадаються: ах, море! ах, море! A як сказати по щирості, - вода, та й годi. Mu не земноводні...» [5, с. 175]. Характеристику обох героїнь доповнює епізод, коли приятельки вирушають «в міський сад на музику», зустрітися з Анатолем, курортним захоплення Алли Михайлівни. Головна героїня намагається всіляко уникнути «такої знайомості», зауваживши: «Съогодні море, он дивітъся, яке гарне, отож я боюсъ, коли б пан Анатоль не зіпсував мені враження своєю особою $i$ розмовою» [5, с. 167]. Від утомливого й беззмістовного спілкування нараторку рятувало море: «Море привабило мене...» [5, с. 172]. Героїня 
захоплена динамічною картиною моря з неперевершеними кольорами і досконалими звуками.

В оповіданні Лесі Українки «Над морем» немає опису оселі, де мешкає нараторка, не подано ㄲï зовнішності чи портрета, позаяк у модерністському творі характеристика героїні, їі стан, різноманіття настроїв «у виконанні» Лесі Українки вишукана - письменниця вдається до ємних описів моря. Водна стихія розкриває вразливу, глибоку й тонку натуру уважної до неповторних митей життя натуру. Море заспокоює нараторку, суголосне їі переконанням, внутрішньому світу, воно знімає втому. Відображені за допомогою моря переживання протагоністки сприяють психологізації художнього твору.

Море з'являється в оповіданні неодноразово i, що прикметно, у моменти дисгармонї нараторки, порушення внутрішньої рівноваги тоді музика моря відновлює гаму почуттів героїні, а також емоційнонастроєву динаміку твору. Це дає підстави зауважити, що панорамні картини моря в оповіданні Лесі Українки - не географічний пейзаж, a, як стверджує I. Денисюк, аналізуючи українську малу прозу кінця XIX - початку XX ст., пейзаж-враження [6, с. 155]. Море - велична стихія - захоплює Лесю Українку своєю могутністю. «А споглядання величі, - наголошує дослідник Г. Башляр, - визначає особливу позииію, своєрідний стан душі, коли бажання виводить мрійника за межі навколишнъого світу, відкриваючи перед ним світ, помічений знаком безкінечності» [7, с.159]. Лесі Українці внутрішньо близькі лісові масиви, що згодом надихнуть, як відомо, на створення неперевершеної драми-феєрії «Лісова пісня». А тут, у Ялті, море стає для Лесі Українки і для головної героїні аналізованого оповідання незвіданою таємничою стихією, сила безмежності якої вражає і притягує. Як засвідчують численні листи Лесі Українки до рідних, споглядаючи і глибоко відчуваючи природу, переживаючи звуки й кольори моря, вона набуває інший (ніж завдяки волинським лісам) досвід роботи над собою, вміє поособливому чути себе, своє хворе тіло. Природний ритм моря позитивно впиває на письменницю.

Перебуваючи тривалий час у Криму, Леся Українка дуже сумує за рідними [3, сс.415, 419, 375, 386 тощо], проте мужньо долає цю вимушену розлуку, потлумачуючи сум і нудьгу по-філософськи мудро [3, с.418]. Підтримувана морем стверджувальна самотність дарує Лесі Українці, як і головній героїні оповідання «Над морем», відчуття зібраності, спокою і внутрішньої цілісності. Так море в оповіданні відкриває дещо приховану, на перший погляд, екзистенційну площину проблематики. Море постає для нараторки, як і для Лесі 
188Літератури світу: поетика, ментальність і духовністъ. 2020. Bип. 14

Українки, психологічним захистом. На думку, Ю. Стадницького, однією з найважливіших особливостей психіки людини є уподібнення простору, що її оточує, до структури «власної душі $i$ власного тіла». Саме тому «простір, у якому ми мешкаємо, несе інформачію про наше глибинне "я", про наш настрій, стан душі» [8, с. 19]. Море допомагає оновитися емоційно й фізично. Звуки моря (спокійне воно чи тривожне) заспокоюють. Головна героїня оповідання апелює до моря - як виразника гармонії та постійності - у хвилини емоційної нестабільності.

Море гоїть душу й тіло Лесі Українки, що засвідчують їі листи з Криму [3, сс. 371-374, 397, 401, 416] [4, с. 10 тощо]. Показовими, скажімо, є такі рядки зі сподіваннями на видужання: «...мені не слід би рано втікати звідси (з Ялти, з Криму. - Л. Г.), - я чую, як весь мій організм на іншу гаму строїться під впливом съого повітря і моря, все більш і більш мною опановуе ideе fiхе, що коли б років три пожила в доброму кліматі, то була б як люди чи хоч коло людей» [3, с. 371]. Море протистоїть хворобі письменниці, бере активну участь у подоланні їі недуги; звуки моря (тобто музика як нереалізовані через хворобу бажання) запускають механізм ігнорування хвороби, зцілення душі й тіла. Саме за допомогою моря Леся Українка блокує у свідомості інформацію про руйнівну силу хвороби, декларує перемогу над життєвими негараздами. Нараторка оповідання «не озвучує» хворобу, лише констатує втому від людей - цю втому нейтралізує море. Так вишукано, відповідно до модерністської практики Леся Українка представляє героїню - чутливу, вразливу, емоційну, яка сприймає досконалі звуки й неперевершені кольори моря як гармонію. «У душі героя перебуває сам писвменник $i$ розглядає інші дійові особи», - зауважує 3. Фройд [9, с. 114], а отже, є підстави, апелюючи до тексту оповідання й листів Лесі Українки з Криму, говорити про невдоволені бажання письменниці бути фізично здоровою, щасливою, що є рушійними силами фантазій, «i кожна окрема фантазія - це здійснення бажань, коректура невдоволеної дійсності» [9, с. 111].

Завдяки морю Леся Українка сподівається на суттєве покращення здоров'я, що необхідно для виснажливої творчої праці. Море альтернативна терапія для душі й тіла Лесі Українки та її головної героїні - нараторки з оповідання «Над морем». Додамо, що під час наступних відвідин Криму таких ємних описів моря та вражень від нього в листах немає. У творі не заявлені вік, соціальний статус головної героїні, зауважено лише, що віддає перевагу самотності та особливо прихильна до моря. Про хворобу чи якусь слабкість не йдеться. 
Висновки й перспективи досліження. Музика в оповіданні Лесі Українки «Над морем» художньо реалізована в фрагментах пісень, музиці оркестрів, у звуках моря. Море є активним компонентом у структуруванні твору, формуванні його музично-настроєвої палітри; «бере активну участь» у відображенні вдачі, внутрішнього стану, корпусу переживань головної героїні, її самодостатності. Панорамні візуально-акустичні описи водної стихії в оповіданні Лесі Українки «Над морем» дають підстави говорити про море як енергетичний канал, джерело емоційного й тілесного відновлення героїні (з ним їй відрадно, спокійно, затишно), своєрідну вісь, що тримає смислову конструкцію твору. Енергія, звуки моря художньо увиразнюють ідею захищеності героїні, котра усвідомлює цінність і повноту буття. Музично-мариністичні акценти письменниці - вдале авторське рішення, покликане оновити жанр, модернізувати підходи до характеристики героїв та увиразнити екзистенційні проблеми. Системне залучення новітніх методологій і міждисциплінарних підходів до аналізу прози Лесі Українки сприятиме вивченню самобутності доробку української письменниці.

\section{Література}

1. Горболіс Л. Музична палітра оповідання Лесі Українки «Над морем». «Усі ріки течуть в море»: мариністика в літературі та культурі: зб. наук. матеріалів конференції (Бердянськ, 26-17 вересня 2019 р.). Бердянськ: БДПУ, 2019. С. 27-29.

2. Мірошниченко Л. Леся Українка. Життя і тексти. Київ: Смолоскип, 2011. $264 \mathrm{c}$.

3. Українка Леся. Твори: у 12 т. Т. 10. Київ: Наукова думка, 1978. $543 \mathrm{c}$.

4. Українка Леся. Твори: у 12 т. Т. 11. Київ: Наукова думка, 1978. $478 \mathrm{c}$.

5. Українка Леся. Твори: у 12 т. Т. 7. Київ: Наукова думка, 1976. 568 с.

6. Денисюк I. Розвиток української малої прози XIX - початку XX ст. Київ: Вища школа, 1981. 215 с.

7. Башляр Г. Избранное: Поэтика пространства. Москва: Российская политическая энциклопедия, 2004. 376 с.

8. Стадницький Ю.ІІ. просторологія: наука про просторові аспекти ефективності. Науковий вісник Ужгородського університету. 2016. Серія «Економіка». Вип. 1 (47). Т. 2. С. 18-22. 
190Літератури світу: поетика, ментальність і духовністъ. 2020. Bип.14

9. Фройд 3. Поет і фантазування // Антологія світової літературнокритичної думки ХХ ст. / за ред. М. Зубрицької. Вид. 2-ге., доп. Львів: Літопис, 2001. 832 с. 